\title{
КОРЕЛЯЦІЙНІ ЗВ’ЯЗКИ РІВНІВ ІНТЕРЛЕЙКІНІВ ТА ПОКАЗНИКІВ ЦИТОКІНОВОГО, ГУМОРАЛЬНОГО ТА КЛІТИННОГО ІМУНІТЕТУ У ХВОРИХ НА РОЗСІЯНИЙ СКЛЕРОЗ ІЗ РІЗНИМИ ТИПАМИ ПЕРЕБІГУ
}

Вступ. Розсіяний склероз (PC) вважають “найзагадковішим" нервовим захворюванням через його непостійність, нестабільність та непередбачуваність, а дослідження імунної системи є невід'ємною частиною діагностики цього захворювання. Тому більш чітке уявлення про імунологічні механізми при різних типах перебігу PC, кореляція їх показників не тільки дозволять поліпшити діагностику та поглибити наші знання про патогенез, але й можуть стати основою для вдосконалення патогенетичного лікування із застосуванням різних імунотерапевтичних засобів.

Мета дослідження - з'ясувати особливості кореляції показників імунопатогенезу цитокінового, гуморального та клітинного імунітету у хворих на розсіяний склероз із різними типами перебігу.

Методи дослідження. Результати досліджень аналізували методом варіаційної статистики за допомогою програми STATISTICA 8.0 ("Statsoft”, США). У всіх обстежуваних визначали рівні інтерлейкінів $1 \beta, 2$, 33, фрактора некрозу пухлини $\alpha$, імуноглобулінів $A, G, M$, а також лімфооцити $C D 3^{+}, C D 4^{+}, C D 8^{+}, C D 19^{+}$, $C D 25^{+}, C D 56^{+}$.

Результати й обговорення. Достовірне підвищення концентрації імуноглобуліну А в сироватці крові пацієнтів із РС вказувало на інфрікованість слизових оболонок, особливо вираженим воно виявилося у хворих з первинно-прогресивним типом перебігу PC. Значне збільшення вмісту імуноглобулінів G і M у сироватці крові пацієнтів із РС свідчило про хронічний перебіг процесу, особливо вираженим воно було при рецидивно-ремітивному типі перебігу РС. Виявлені коливання середнього вмісту циркулювальних імунних комплексів у сироватці крові пацієнтів із РС вказували на ступінь тяжкості імунопатологічного процесу. В групі хворих із вторинно-прогресивним типом перебігу РС між показниками імунного статусу і рівнями інтерлейкінів 1及, 2, 33 та фрактора некрозу пухлини а спостерігали значну кількість сильних кореляційних зв'язків і зв'язків середньої сили. Рівень інтерлейкіну 2 у всіх обстежених пацієнтів із РС мав найбільше кореляційних зв'язків із показниками імунного статусу, що свідчило про його важливу участь у патогенезі $P C$.

Висновок. Дослідження кореляційних зв'язків цитокінів, а також інших показників гуморального та клітинного імунітету у хворих на розсіяний склероз $є$ актуальним і перспективним напрямком для вивчення механізмів імунопатогенезу цього захворювання та його корекції.

КЛЮЧОВІ СЛОВА: розсіяний склероз; кореляція; цитокіни; лімфоцити; імуноглобуліни; циркулювальні імунні комплекси.

ВСТУП. Розсіяний склероз (РС) на даний час розглядають як багатосракторне хронічне захворювання, таке, що прогресує і характеризується переважним ураженням центральної нервової системи, насамперед білої речовини (демієлінізація), а також, за останніми даними, і сірої (дегенерація), провідним патофрізіологічним механізмом при цьому є запалення та аутоімунні процеси [1, 2]. Проте механізми виникнення та підходи до лікування даного захворювання все ще недостатньо вивчено. Розсіяний склероз (ㄱ Р. Я. Вівчар, Т. Я. Ярошенко, 2019. вважають "найзагадковішим" нервовим захворюванням через його непостійність, нестабільність та непередбачуваність [3].

На сьогодні доведено провідну роль імунопатологічних реакцій у патогенезі РС, а дослідження імунної системи є невід'ємною частиною діагностики цього захворювання.

Аналіз останніх досліджень. У більшості пацієнтів (85-90 \%) перебіг хвороби від початку $€$ рецидивним і характеризується загостренням неврологічних симптомів, пов'язаних із зонами запалення в центральній нервовій системі. Про- 
тягом двох десятиліть у понад половини нелікованих хворих відзначають поступове погіршення стану незалежно від тяжкості нападів [4-6]. Первинно-прогресивний перебіг розсіяного склерозу спостерігають приблизно в 10-15 \% випадків $[7,8]$.

На сьогодні немає методів радикального лікування цієї патології, тому сучасна терапевтична стратегія спрямована на зниження ризику виникнення рецидивів і прогресування інвалідності [9]. Більш чітке уявлення про імунологічні механізми при різних формах РC, кореляція їх показників не тільки дозволять поліпшити діагностику та поглибити наші знання про патогенез, але й можуть стати основою для вдосконалення патогенетичного лікування із застосуванням різних імунотерапевтичних засобів $[10,11]$.

Мета дослідження - 3'ясувати особливості кореляції показників імунопатогенезу цитокінового, гуморального та клітинного імунітету у хворих на розсіяний склероз із різними типами перебігу.

МЕТОДИ ДОСЛІДЖЕННЯ. РезуЛьтати досліджень аналізували методом варіаційної статистики за допомогою програми STATISTICA 8.0 ("Statsoft", США). 3 метою виявлення кореляційних зв'язків визначали коефіцієнт лінійної кореляції |r| між усіма досліджуваними показниками.
Силу зв'язку оцінювали за абсолютним значенням лінійного коефріцієнта кореляції Пірсона, вважаючи, що при $r \leq 0,25$ взаємозв'язок слабкий, при 0,25<r<0,75 взаємозв'язок середньої сили, при $r \geq 0,75$ кореляційний зв'язок сильний. У всіх обстежуваних визначали рівні інтерлейкінів (IL) $1 \beta, 2,33$, фрактора некрозу пухлини а (TNF $\alpha)$, імуноглобулінів (Ig) A, G, M, а також лімфоцити $\mathrm{CD}^{+}, \mathrm{CD}^{+}, \mathrm{CD}^{+}, \mathrm{CD}^{2} 9^{+}, \mathrm{CD}^{2} 5^{+}, \mathrm{CD}^{+} 6^{+}$.

РЕЗУЛЬТАТИ Й ОБГОВОРЕННЯ. РіВеНЬ інтерлейкіну $1 \beta$ у сироватці крові хворих з первинно-прогресивним типом перебігу РС мав сильні негативні кореляційні зв'язки з рівнями: IL33 $(r=-0,98 ; p<0,05), \mathrm{CD}^{+}(r=-0,78 ; p<0,05)$, $\mathrm{CD}^{+}(\mathrm{r}=-0,97 ; p<0,05)$; сильні позитивні кореляційні зв'язки з рівнями: $\lg M(r=0,94 ; p<0,05)$; Ig $A(r=0,95 ; p<0,05) ; C_{1} 19^{+}(r=0,92 ; p<0,05)$ (рис. 1).

Середньої сили кореляційні зв'язки рівня IL1ß у сироватці крові хворих із вториннопрогресивним типом перебігу РС були: негативні - з рівнем CD8 ${ }^{+}(r=-0,58 ; p<0,05)$; позитивні - із вмістом TNFa $(r=0,68 ; p<0,05), \mathrm{CD}^{+} 6^{+}(r=0,67$; $p<0,05)$. Рівень IL1 $\beta$ у сироватці крові хворих із вторинно-прогресивним типом перебігу РС мав сильні позитивні кореляційні зв'язки з рівнями: $\mathrm{CD}_{19}{ }^{+}(r=0,89 ; p<0,05), \lg \mathrm{A}(r=0,91 ; p<0,05), \lg \mathrm{M}$ $(r=0,90 ; p<0,05)$ (рис. 2).

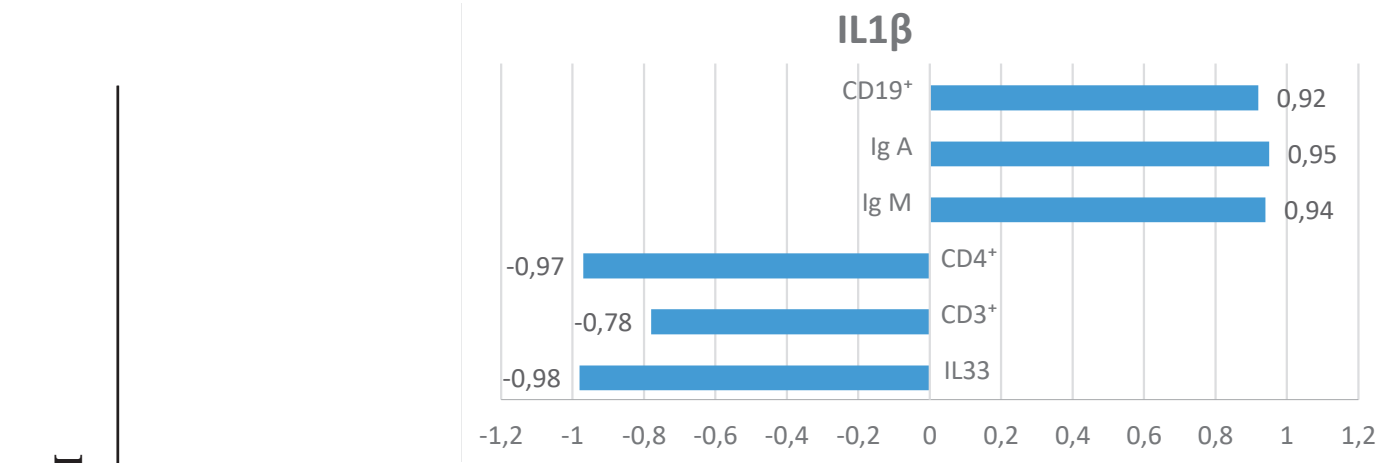

Рис. 1. Кореляційні зв'язки між рівнем інтерлейкіну $1 \beta$ у сироватці крові та показниками імунного статусу хворих 3 первинно-прогресивним типом перебігу розсіяного склерозу.

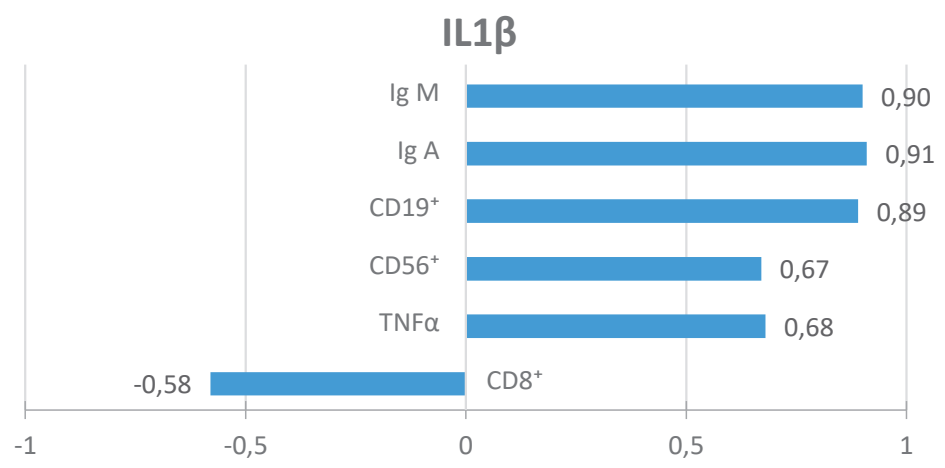

Рис. 2. Кореляційні зв'язки між рівнем інтерлейкіну $1 \beta$ у сироватці крові та показниками імунного статусу хворих із вторинно-прогресивним типом перебігу розсіяного склерозу. 
Сильні негативні кореляційні зв'язки вміст IL1 $\beta$ у сироваці крові хворих з рецидивноремітивним типом перебігу РС мав із рівнями: $\mathrm{CD}^{+}(r=-0,81 ; p<0,05), \mathrm{CD}^{+}(r=-0,89 ; p<0,05)$, IL33 $(r=-0,96 ; p<0,05)$, Ig $A(r=-0,89 ; p<0,05)$. Середньої сили кореляційні зв'язки рівня IL1ß у сироватці крові були: негативні - 3 рівнями $\mathrm{CD}^{+}$ $(r=-0,64 ; p<0,05)$, IL2 ( $r=-0,26 ; p<0,05)$; позитивні 3 рівнями CD56 ${ }^{+}(r=0,62 ; p<0,05), C^{2} 25^{+}(r=0,31$; $p<0,05)$, TNFa $(r=0,63 ; p<0,05)$ (рис. 3).

Виявлено ряд кореляційних зв'язків між рівнем IL2 у хворих з первинно-прогресивним типом перебігу РС та досліджуваними показниками (рис. 4).

Сильні негативні кореляційні зв'язки вміст IL2 мав із рівнями TNFa $(r=-0,97 ; p<0,05), \lg G$ $(r=-0,92 ; p<0,05)$ та CD25+ $(r=-0,98 ; p<0,05)$; сильні позитивні - 3 рівнем IL33 $(r=0,98 ; p<0,05)$ та вмістом TNFa $(r=0,82 ; p<0,05)$. Рівень IL2 у хворих із вторинно-прогресивним типом перебігу РС мав середньої сили негативні зв'язки 3 рівнями Ig $M(r=-0,52 ; p<0,05)$, Ig $A(r=-0,56$; $p<0,05)$, а також вмістом CD8+ $(r=-0,71 ; p<0,05)$, CD3+ $(r=-0,49 ; p<0,05)$; середньої сили позитивні зв'язки - 3 рівнями CD56+ $(r=0,65 ; p<0,05)$ i $\mathrm{CD} 19+(r=0,31 ; p<0,05)$ (рис. 5).

Сильні негативні кореляційні зв'язки виникли між рівнем IL2 у сироватці крові хворих з рецидивно-ремітивним типом перебігу РС та рівнями TNF $\alpha(r=-0,77 ; p<0,05)$, Ig $G(r=-0,98 ; p<0,05)$, $\mathrm{CD}_{2} 5^{+}(r=-0,99 ; p<0,05)$ та CD8 ${ }^{+}(r=-0,82 ; p<0,05)$ (рис. 6).

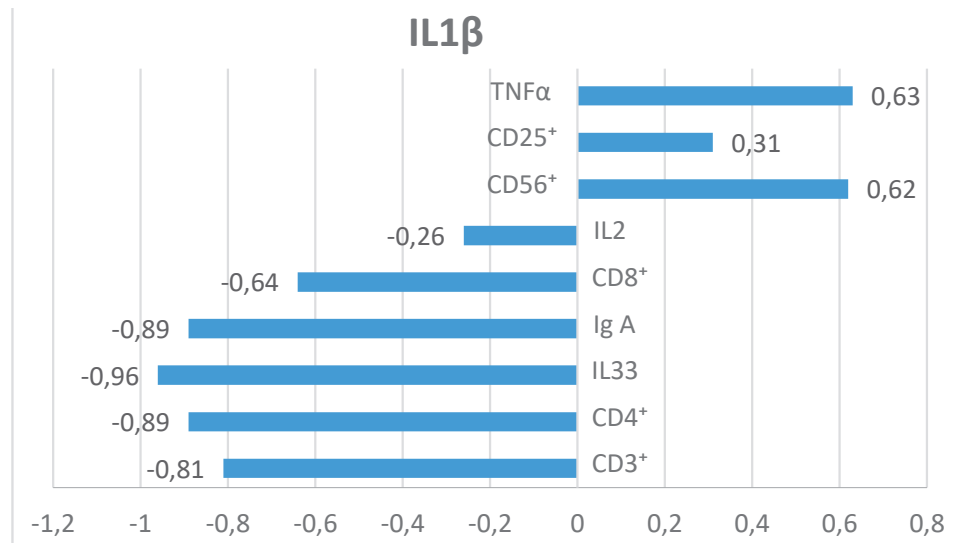

Рис. 3. Кореляційні зв'язки між рівнем інтерлейкіну $1 \beta$ у сироватці крові та показниками імунного статусу хворих 3 рецидивно-ремітивним типом перебігу розсіяного склерозу.

\section{IL2}

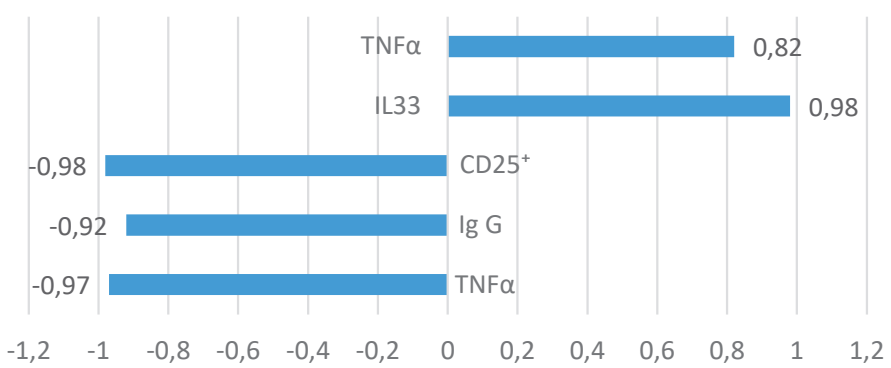

Рис. 4. Кореляційні зв'язки між рівнем інтерлейкіну 2 у сироваці крові та показниками імунного статусу хворих 3 первинно-прогресивним типом перебігу розсіяного склерозу.

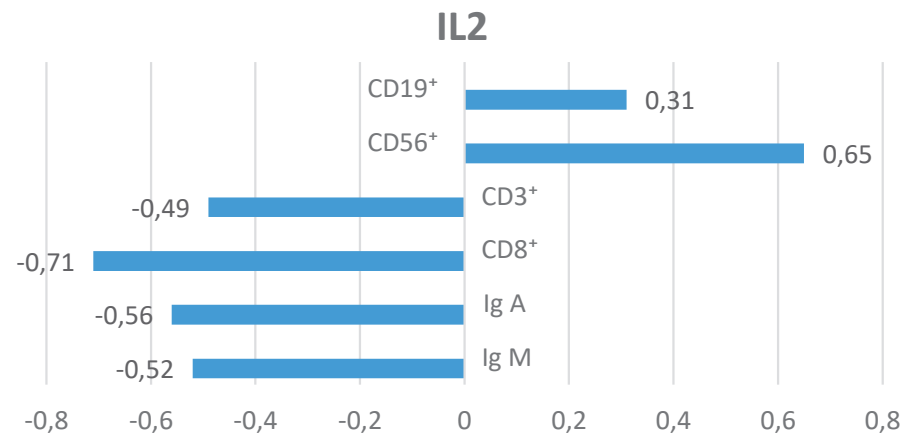

Рис. 5. Кореляційні зв'язки між рівнем інтерлейкіну 2 у сироватці крові та показниками імунного статусу хворих із вторинно-прогресивним типом перебігу розсіяного склерозу. 
Кореляційні зв'язки між рівнем IL33 та іншими досліджуваними показниками хворих з різними типами перебігу РС були різної сили і спрямування. Сильні негативні кореляційні зв'язки виявлено між рівнем IL33 у сироватці крові хворих з первинно-прогресивним типом перебігу PC і рівнями TNF $\alpha(r=-0,88 ; p<0,05), \lg G$ $(r=-0,98 ; p<0,05), C^{2} 5^{+}(r=-0,98 ; p<0,05), C^{+}$ $(r=-0,88 ; p<0,05)$ (рис. 7).

Сильні позитивні кореляційні зв'язки виникли між рівнем IL33 у хворих із вторинно-прогресивним типом перебігу PC і рівнями $\mathrm{CD}^{+}(\mathrm{r}=0,89$; $p<0,05), \mathrm{CD}^{+}(r=0,78 ; p<0,05)$, TNFa $(r=0,89$; $\mathrm{p}<0,05)$ (рис. 8).

Середньої сили негативні кореляційні зв'язки виникли між рівнем IL33 у сироватці крові хворих з рецидивно-ремітивним типом перебігу $\mathrm{PC}$ та рівнями $\lg \mathrm{M}(\mathrm{r}=-0,45 ; \mathrm{p}<0,05), \lg \mathrm{A}(\mathrm{r}=-0,54$; $p<0,05)$ та $\mathrm{CD}^{+}(r=-0,58 ; p<0,05)$. Позитивні кореляційні зв'язки середньої сили були між рівнем
IL33 та рівнями $\mathrm{CD}^{+} 6^{+}(\mathrm{r}=0,77 ; \mathrm{p}<0,05), \mathrm{CD}^{+}$ $(r=0,45 ; p<0,05)$ (рис. 9).

Ряд кореляційних зв'язків було виявлено між рівнем TNF $\alpha$ в сироватці крові хворих з первинно-прогресивним типом перебігу РС та іншими досліджуваними показниками (рис. 10): сильний негативний - із рівнями Ig M ( $r=-0,95 ; p<0,05)$, $\lg A(r=-0,97 ; p<0,05)$ i $C D 19^{+}(r=-0,88 ; p<0,05)$; сильний позитивний - із рівнем секреторного Ig $A(r=0,84 ; p<0,05)$ та вмістом $\mathrm{CD}^{+}(r=0,95$; $p<0,05)$ і $\mathrm{CD}^{+}(r=0,85 ; p<0,05)$; середньої сили негативний зв'язок - із вмістом $\mathrm{CD}^{\prime} 6^{+}(\mathrm{r}=-0,65$; $\mathrm{p}<0,05)$; середньої сили позитивний зв'язок - із рівнем CD8 $(r=0,66 ; p<0,05)$.

Рівень TNFa в сироватці крові хворих із вторинно-прогресивним типом перебігу РС мав кореляційні зв'язки сильного негативного характеру (рис. 11) з рівнями $\lg A(r=-0,84 ; p<0,05)$, $\lg G(r=-0,95 ; p<0,05), \mathrm{CD}^{+}(r=-0,82 ; p<0,05)$, $\mathrm{CD}^{+}(r=-0,98 ; p<0,05), \mathrm{CD}^{+} 5^{+}(r=-0,89 ; p<0,05)$.

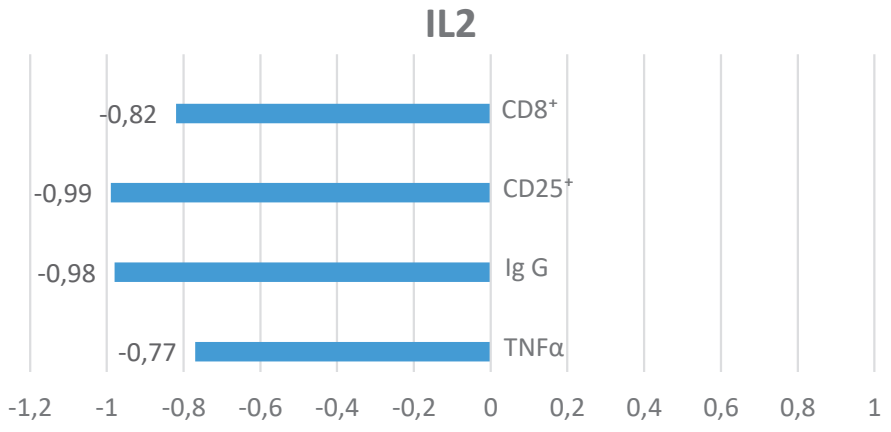

Рис. 6. Кореляційні зв'язки між рівнем інтерлейкіну 2 у сироватці крові та показниками імунного статусу хворих 3 рецидивно-ремітивним типом перебігу розсіяного склерозу.

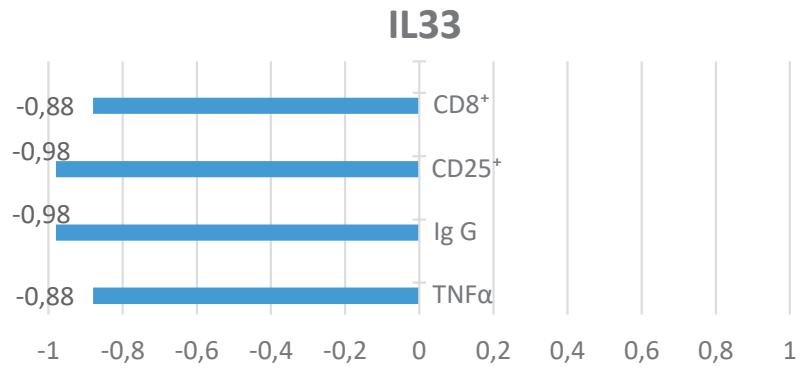

Рис. 7. Кореляційні зв'язки між рівнем інтерлейкіну 33 у сироватці крові та показниками імунного статусу хворих 3 первинно-прогресивним типом перебігу розсіяного склерозу.

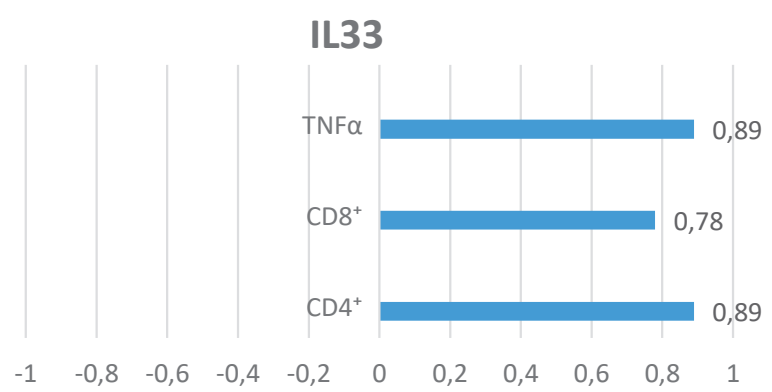

Рис. 8. Кореляційні зв'язки між рівнем інтерлейкіну з3 у сироватці крові та показниками імунного статусу хворих із вторинно-прогресивним типом перебігу розсіяного склерозу. 
Сильні позитивні зв'язки були між рівнем TNFa в сироватці крові хворих із вторинно-прогресивним типом перебігу РС та вмістом $\mathrm{CD}_{19}{ }^{+}(\mathrm{r}=0,86$; $p<0,05)$ i CD56+ $(r=0,98 ; p<0,05)$.

Середньої сили кореляційні зв'язки рівня TNFa в сироватці крові хворих з рецидивно-

ремітивним типом перебігу РС були: негативні 3 рівнем CD4+ $(r=-0,56 ; p<0,05) ;$ позитивні - 3 рівнем CD56+ $(r=0,55 ; p<0,05)$ (рис. 12). Кореляційні зв'язки сильного характеру були між рівнем TNFa в сироватці крові хворих із рецидивноремітивним типом перебігу РС та показниками

\section{L33}

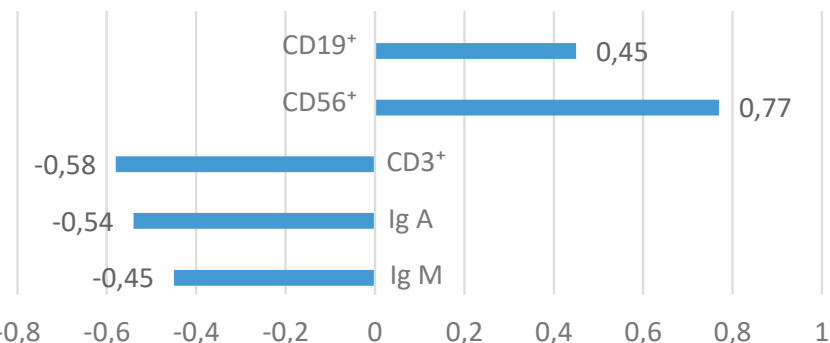

Рис. 9. Кореляційні зв'язки між рівнем інтерлейкіну 33 у сироватці крові та показниками імунного статусу хворих 3 рецидивно-ремітивним типом перебігу розсіяного склерозу.

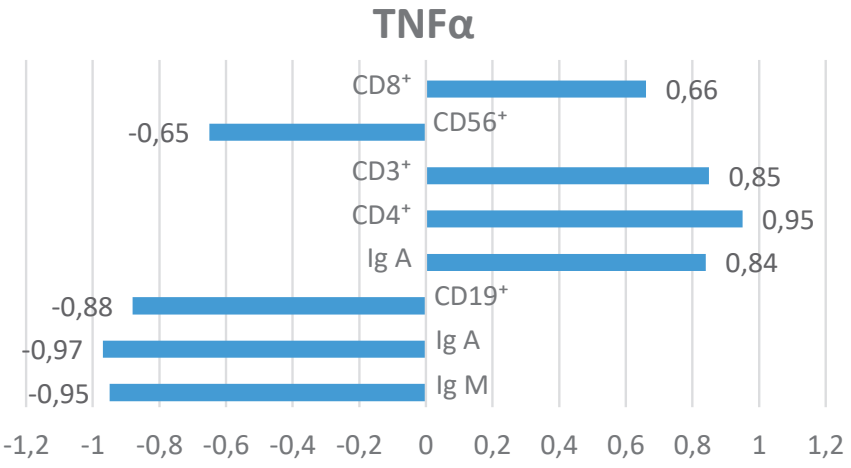

Рис. 10. Кореляційні зв'язки між рівнем срактора некрозу пухлини а в сироватці крові та показниками імунного статусу хворих з первинно-прогресивним типом перебігу розсіяного склерозу.

TNF $\alpha$

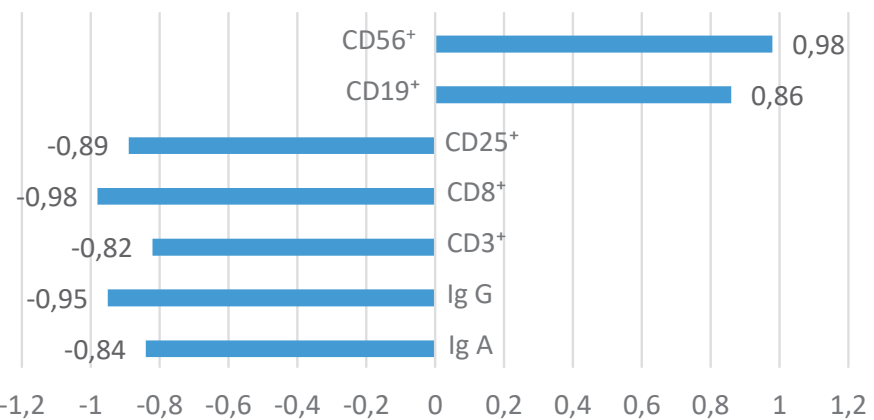

Рис. 11. Кореляційні зв'язки між рівнем фрактора некрозу пухлини а в сироватці крові та показниками імунного статусу хворих із вторинно-прогресивним типом перебігу розсіяного склерозу.

\section{TNF $\alpha$}

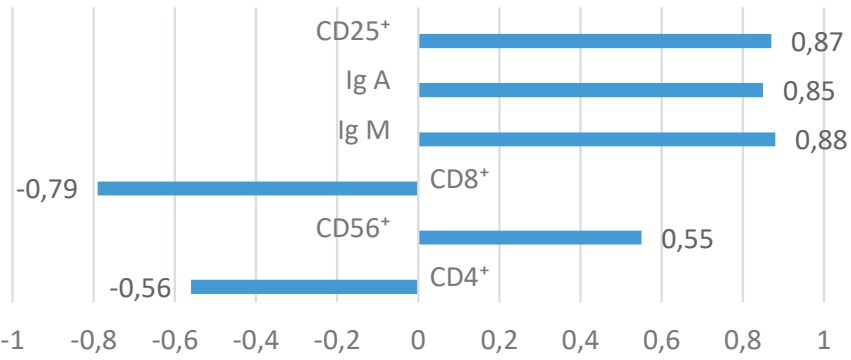

Рис. 12. Кореляційні зв'язки між рівнем фрактора некрозу пухлини а в сироватці крові та показниками імунного статусу хворих з рецидивно-ремітивним типом перебігу розсіяного склерозу. 
імунного статусу: сильний негативний зв'язок виник із рівнем $\mathrm{CD}^{+}$в сироватці крові $(\mathrm{r}=-0,79$; $\mathrm{p}<0,05)$; сильний позитивний - із рівнями Ig М $(r=0,88 ; p<0,05), \lg A(r=0,85 ; p<0,05)$, а також вмістом CD25+ $(r=0,87 ; p<0,05)$.

ВИСНОВКИ. 1. У групі хворих із вторинно-прогресивним типом перебігу РС між показниками імунного статусу та рівнями інтерлейкінів $1 \beta, 2,33$ та фрактора некрозу пухлини $\alpha$ виявлено значну кількість сильних кореляційних зв'язків і зв'язків середньої сили.

2. Рівень інтерлейкіну 2 у всіх обстежених хворих на РС мав найбільше кореляційних зв'язків із показниками імунного статусу, що свідчить про його важливу участь у патогенезі захворювання.

3. Високий рівень інтерлейкіну $1 \beta$ у сироватці крові хворих із первинно-прогресивним (у 3,7 раза вище норми) та вторинно-прогресивним (у 2,8 раза вище норми) типами перебігу PC свідчить про компенсаторні реакції організму.
4. У хворих на розсіяний склероз спостерігають дисбаланс гуморальної ланки імунітету. Вiрогідне збільшення концентрації імуноглобуліну А в сироватці крові хворих на РС вказує на інфрікування слизових оболонок, яке особливо виражене в пацієнтів з первинно-прогресивним типом перебігу PC. Значне зростання вмісту імуноглобуліну $G$ у сироватці крові пацієнтів із РС свідчить про хронічний перебіг процесу, особливо виражено проявляється при рецидивно-ремітивному типі перебігу РС. Підвищення концентрації імуноглобуліну М у сироватці крові хворих на PC може свідчити про загострення перебігу хронічного запалення, особливо при рецидивно-ремітивному типі перебігу розсіяного склерозу.

Перспективи подальших досліджень. Дослідження кореляційних зв'язків цитокінів, а також інших показників гуморального та клітинного імунітету у хворих на розсіяний склероз $\epsilon$ актуальним і перспективним напрямком для вивчення механізмів імунопатогенезу цього захворювання та його корекції.

\section{СПИСОК ЛІТЕРАТУРИ}

1. Compston A. Multiple sclerosis / A. Compston, A. Coles // Lancet. - 2008. - 372. - P.1502-1517. doi:10.1016/S0140-6736(08)61620-7. Epub 2008 October.

2. Diagnostic criteria for multiple sclerosis: 2010 revisions to the McDonald criteria / C. H. Polman, S. C. Reingold, B. Banwell [et al.] //Ann. Neurol. -2011. 69, Issue 2. - P. 292-302.

3. Биомаркеры рассеянного склероза (обзор и собственные данные / А. А. Воробьева, М. В. Иванова, В. В. Фоминых [и др.] // Журн. неврологии и психиатрии им. С. С. Корсакова. - 2013. - 113, № 10. C. 23-31.

4. Волошина Н. П. Гендерные особенности иммунного статуса при прогредиентных типах течения рассеянного склероза [Текст] / Н. П. Волошина, И. Л. Левченко, Т. В. Негреба // Укр. вісн. психоневрології. - 2011. - 19, № 4. - С. 5-9.

5. Дисбаланс цикотинов как один из прогностических критериев рассеянного склероза / С. Е. Гуляева, Л. А. Иванушко, А. В. Овчинников [и др.] // Тихоокеанский мед. журн. - 2010. - № 42 (4). - С. 55-58.

6. Tsang B. K. Multiple sclerosis - diagnosis, management and prognosis [Text] / B. K. Tsang, R. Macdonell // Aust. Fam. Physician. - 2011. - No. 40 (12). P. 948-955.

7. Бойко А. Н. Выбор оптимального препарата для патогенетического лечения рассеянного склеро- за: современное состояние проблемы (обзор литературы) [Текст] / А. Н. Бойко, О. В. Бойко, Е. И. Гусев // Журн. неврологии и психиатрии им. С. С. Корсакова. 2014. - 114, Прил. к № 10 (Вып. 2. Рассеянный склероз). - С. 77-91.

8. Макаров С. В. Клинико-иммунологическая характеристика больных с ремиттирующим и прогрессирующим течением рассеянного склероза [Текст] / С. В. Макаров // Фундаментальные исследования. 2014. - № 4. - С. 546-550.

9. Возможности лечения обострений рассеянного склероза без применения кортикостероидов: роль метаболической и антиоксидантной терапии [Текст] / Г. Н. Бисага, М. М. Одинак, А. Н. Бойко [и др.] // Журн. неврологии и психиатрии им. С. С. Корсакова. 2011. - 111, № 2. - С. 44-48.

10. Клинико-электрофизиологическая и молекулярно-генетическая характеристика течения ремиттирующего рассеянного склероза [Текст] / Р. А. Делов, А. С. Рождественский, Е. А. Маркс [и др.] // Журн. неврологии и психиатрии им. С. С. Корсакова. 2013. - 113, № 10. - C. 55-59.

11. Recommended diagnostic criteria for multiple sclerosis: guidelines from the International Panel on the diagnosis of multiple sclerosis[Text] / W. I. McDonald, A. Compston, G. Edan // Ann. Neurol. -2001. -No. 50 (1). P. 121-127. 


\section{REFERENCES}

1. Compston, A., \& Coles, A. (2008). Multiple sclerosis. Lancet, 372 (9648), 1502-1517. PMID 18970977. doi:10.1016/S0140-6736(08)61620-7.

2. Polman, C.H., Reingold, S.C., Banwell, B., Clanet, M., Cohen, J.A., Filippi, M. et al. (2011). Diagnostic criteria for multiple sclerosis: 2010 revisions to the McDonald criteria. Ann. Neurol., 69 (2), 292-302.

3. Vorobyeva, A.A., Ivanova, M.V., Fominykh, V.V., Zakharova, M.N., Zygangyrova, G.A., \& Gulyaeva, N.V. (2013). Biomarkery rasseyannogo skleroza (obzor i sobstvennyye dannyye) [Multiple sclerosis biomarkers (review and own data)]. Zhurnal nevrologii i psikhiatrii im. S. S. Korsakova - S.S. Korsakov Journal of Neurology and Psychiatry, 113 (10), 23-31 [in Russian].

4. Voloshina, N.P., Levchenko, I.L., \& Negreba, T.V. (2011). Gendernyye osobennosti immunnogo statusa pri progrediyentnykh tipakh techeniya rasseyannogo skleroza [Gender features of immune status in progressive types of multiple sclerosis]. Ukr. vestnik psikhonevrologii Ukrainian Bulletin of Psychoneurology, 19 (4), 5-9 [in Russian].

5. Gulyayeva, S.Ye., Ivanushka, L.A., Ovchinnikov, A.V., Besednova, N.A., Korotkova, M.A., Sharkova, V.A. (2010). Disbalans tsitokinov kak odin iz prognosticheskikh kriteriyev rasseyannogo skleroza [An imbalance of cytokines as one of the prognostic criteria for multiple sclerosis]. Tikhookeanskiy meditsinskiy zhurnal - Pacific Medical Journal, 42 (4), 55-58 [in Russian].

6. Tsang, B.K., \& Macdonell, R. (2011). Multiple sclerosis-diagnosis, management and prognosis. Aust. Fam. Physician, 40 (12), 948-955.

7. Boyko, A.N., Boyko, A.V., Gusev, Ye.I. (2014). Vybor optimalnogo preparata dlya patogeneticheskogo lecheniya rasseyannogo skleroza: sovremennoye sostoyaniye problemy (obzor literatury) [Choosing the best drug for the pathogenetic treatment of multiple sclerosis: the current state of the problem (literature review)]. Zhurnal nevrologii i psikhiatrii im. S.S. Korsakova S.S. Korsakov Journal of Neurology and Psychiatry, 20, 114 (10), 77-91 [in Russian].

8. Makarov, S.V. (2014). Kliniko-immunologicheskaya kharakteristika bolnykh s remittiruyushchim i progressiruyushchim techeniyem rasseyannogo skleroza [Clinical and immunological characteristics of patients with remitting and progressing course of multiple sclerosis]. Fundamentalnyye issledovaniya - Basic Research, 4, 546-550 [in Russian].

9. Bisaga, A.N., Odinochka, M.M., \& Boyko, A.N. (2011). Vozmozhnosti lecheniya obostreniy rasseyannogo skleroza bez primeneniya kortikosteroidov: rol metabolicheskoy i antioksidantnoy terapii [Possibilities of treating exacerbations of multiple sclerosis without corticosteroids: the role of metabolic and antioxidant therapy]. Zhurnal nevrologii i psikhiatrii im. S. S. Korsakova - S.S. Korsakov Journal of Neurology and Psychiatry, 111 (2), 44-48 [in Russian].

10. Delov, G.A., Rozhdestvenskiy, A.S., \& Marks, Y.A. (2013). Kliniko-elektrofiziologicheskaya i molekulyarnogeneticheskaya kharakteristika techeniya remittiruyushchego rasseyannogo skleroza [Clinical-electrophysiological and molecular-genetic characteristics of the course of remitting multiple sclerosis]. Zhurnal nevrologii i psikhiatrii im. S.S. Korsakova - S.S. Korsakov Journal of Neurology and Psychiatry, 113 (10), 55-59 [in Russian].

11. McDonald, W.I., Compston, A., Edan, G., Goodkin, D., Hartung, H.P., Lublin, F.D. (Eds.). (2001). Recommended diagnostic criteria for multiple sclerosis: guidelines from the International Panel on the diagnosis of multiple sclerosis. Ann. Neurol., 50 (1), 121-127.

\section{Р. Я. Вивчар ${ }^{1}$, Т. Я. Ярошенко ${ }^{2}$ ЛЬВОВСКИЙ НАЦИОНАЛЬНЫЙ МЕДИЦИНСКИЙ УНИВЕРСИТЕТ ИМЕНИ ДАНИЛА ГАЛИЦКОГО ТЕРНОПОЛЬСКИЙ НАЦИОНАЛЬНЫЙ МЕДИЦИНСКИЙ УНИВЕРСИТЕТ ИМЕНИ И. Я. ГОРБАЧЕВСКОГО}

МОЗ УКРАИНЫ ${ }^{2}$

\section{КОРРЕЛЯЦИОННЫЕ СВЯЗИ УРОВНЕЙ ИНТЕРЛЕЙКИНОВ И ПОКАЗАТЕЛЕЙ ЦИТОКИНОВОГО, ГУМОРАЛЬНОГО И КЛЕТОЧНОГО ИММУНИТЕТА У БОЛЬНЫХ РАССЕЯННЫМ СКЛЕРОЗОМ С РАЗНЫМИ ТИПАМИ ТЕЧЕНИЯ}

\section{Резюме}

Вступление. Рассеянный склероз (РC) считают “самым загадочным" нервным заболеванием из-за его непостоянства, нестабильности и непредсказуемости, а исследования иммунной системы являются неотъемлемой частью диагностики этого заболевания. Поэтому более четкое представление о иммунологических механизмах при различных типах течения $\mathrm{PC}$, корреляция их показателей не только позволят улучшить диагностику и углубить наши знания о патогенезе, но и могут стать основой для усовершенствования патогенетического лечения с применением различных иммунотерапевтических средств.

Цель исследования - выяснить особенности корреляции показателей иммунопатогенеза цитокинового, гуморального и клеточного иммунитета у больных рассеянным склерозом с различными типами течения.

Методы исследования. Результаты исследований анализировали методом вариационной статистики с помощью программы STATISTICA 8.0 ("Statsoft", США). У всех обследуемых определяли уровни интерлейкинов 1及, 2, 33, фрактора некроза опухоли $\alpha$, иммуноглобулинов $A, G, M$, а также лимороциты $C D 3^{+}$, $C D 4^{+}, C D 8^{+}, C D 19^{+}, C D 25^{+}, C D 56^{+}$. 
Результаты и обсуждение. Достоверное повышение концентрации иммуноглобулина А в сыворотке крови пациентов с РС указывало на инфицированность слизистых оболочек, особенно выраженным оно оказалось у больных с первично-прогрессирующим типом течения РС. Значительное увеличение содержания имуноглобулинов G и М в сыворотке крови пациентов с РС свидетельствовало о хроническом течении процесса, особенно выраженным оно было при рецидивирующе-ремитирующем типе течения PC. Обнаруженные колебания среднего содержания циркулирующих иммунных комплексов в сыворотке крови пациентов с РС указывало на степень тяжести иммунопатологического процесса. В группе больных с вторично-прогрессирующим типом течения PC между показателями иммунного статуса и уровнями интерлейкинов 1及, 2, 33 и фрактора некроза опухоли $\alpha$ наблюдали значительное количество сильных корреляционных связей и связей средней силы. Уровень интерлейкина 2 у всех обследованных пациентов с РС имел наибольшее число корреляционных связей с показателями иммунного статуса, что свидетельствовало о его важном участии в патогенезе PC.

Вывод. Исследование корреляционных связей цитокинов, а также других показателей гуморального и клеточного иммунитета у больных рассеянным склерозом является актуальным и перспективным направлением для изучения механизмов иммунопатогенеза этого заболевания и его коррекции.

КЛЮЧЕВЫЕ СЛОВА: рассеянный склероз; корреляция; цитокины; лимфоциты; иммуноглобулины; циркулирующие иммунные комплексы.

R. Ya. Vivchar, T. Ya. Yaroshenko DANYLO HALYTSKYI LVIV NATIONAL MEDICAL UNIVERSITY ${ }^{1}$ I. HORBACHEVSKY TERNOPIL NATIONAL MEDICAL UNIVERSITY²

\title{
CORRELATIONS BETWEEN INTERLEUKIN LEVELS AND INDICES OF CELL-MEDIATED AND HUMORAL IMMUNITIES IN PATIENTS WITH MULTIPLE SCLEROSIS IN DIFFERENT COURSES OF THE DISEASE
}

\begin{abstract}
Summary
Introduction. Multiple sclerosis (MS) is considered the "most mysterious" nerve disease due to its volatility, instability and unpredictability, and research on the immune system is an integral part of the diagnosis of the disease. Therefore, a clearer idea of the immunological mechanisms in various forms of MS, correlation of their indicators will not only improve the diagnosis and deepen our knowledge of pathogenesis, but can also be the basis for improving pathogenetic treatment with the use of various immunotherapeutic agents.

The aim of the study - to find out the features of correlation of immunopathogenesis indices, cytokine, humoral and cell immunity in patients with multiple sclerosis with different types of the course.

Research Methods. The results of the studies were analyzed by the method of variational statistics using STATISTICA 8.0 (Statsoft, USA).

Results and Discussion. Levels of interleukins $1 \beta, 2,33, T N F-\alpha$, immunoglobulins $A, G, M$ and the content of circulating immune complexes (CIC), as well as $C D 3^{+}, C D 4^{+}, C D 8^{+}, C D 19^{+}, C D 25^{+}, C D 56^{+}$lymphocytes were studied in all individuals under investigation. A reliable increase in IgA concentration in blood serum of patients with MS indicates infection of the mucosa. It was especially marked in patients with primary progressive form of MS. Significant increase in IgG and IgM levels in blood serum of patients with MS indicates a chronic course of the process. It is especially evident in relapsing-remitting form of MS. Fluctuations in mean content of circulating immune complexes in blood serum of patients with MS indicate the severity degree of immunopathological process. A significant number of strong and moderate correlations between indices of immune status and the levels of interleukins $I L-1 \beta, I L-2, I L-33$ and TNF- $\alpha$ has been revealed in the group of patients with secondary progressive type of MS. The level of IL-2 in all investigated groups of patients with PC constituted the highest number of correlations with immune status indices, which proves its important role in MS pathogenesis.

Conclusion. Investigation of cytokine correlations as well as other indices of humoral and cellular immunity in patients with MS is a relevant and promising area for studying the mechanisms of PC immunopathogenesis and its correction.
\end{abstract}

KEY WORDS: multiple sclerosis; correlation; cytokines; lymphocytes; immunoglobulins; circulating immune complexes.

Отримано 11.10.19

Адреса для листування: Р. Я. Вівчар, вул. Тракт Глинянський, 153А, кв. 61, Львів, 79067, Україна, e-mail: romanviv@gmail.com. 